British Journal of Education

Vol.8, Issue 3, pp.1-15, March 2020

Published by ECRTD- UK

Print ISSN: ISSN 2054-6351

Online ISSN: ISSN 2054-636X

\title{
IMPACT OF EARLY READING SKILLS AND TEACHERS PERCEPTIONS IN ENGLISH AS A FOREIGN LANGUAGE USING ICT: EVIDENCE FROM VIETNAM
}

\author{
${ }^{1}$ Truong Thi Hong Thuy \\ School of Education Science, Minnan Normal University, Zhangzhou, P.R. China \\ truongthihongthuy23@gmail.com
}

2*Sikandar Ali Qalati

School of Management, Department of Marketing, 301 Xuefu Road, Jingkou District, Zhenjiang, Jiangsu, P.R. China

5103180243@stmail.ujs.edu.cn

${ }^{3}$ Sajid Hussain Merani

Department of Public Administration, Shah Abdul Latif University, Khairpur, Sindh, Pakistan sajidmirani@hotmail.com

\begin{abstract}
This study aimed to identify the early reading skills in English as a foreign language via information and communication technology in Vietnam as well as early childhood student teachers perception. Currently, information and communication technology and part of the teacher's perception in the classroom practices performed an effective role in the learning aptitude of students and enhanced their reading skills in English as a foreign language. The nature of the study was cross-sectional and data were collected from 100 students and teachers from Hanoi National University of Education. The output of the study revealed that more students were agreed and had a positive perception towards the uses of information and communication technology in teaching reading in English as a foreign language. The results also indicated that teachers used the best skills and strategies to enhance children's vocabulary in the classrooms. Lastly, findings indicated that students faced a lack of resources and technical support as significant barriers. Implications for early childhood pre-service teacher training and educational policy are discussed.
\end{abstract}

KEYWORDS: early childhood education, reading, and skills, barriers, strategies, students, teacher's perception, Vietnam

\section{INTRODUCTION}

The rapid development of information technology has made potential commitments to English language instruction for as far back as hardly any decades. The utilization of innovations gives students rare chances to rehearse English and include themselves in bona fide situations of 
British Journal of Education

Vol.8, Issue 3, pp.1-15, March 2020

Published by ECRTD- UK

Print ISSN: ISSN 2054-6351

Online ISSN: ISSN 2054-636X

language use (Stephen and Edwards 2018). The present small kids associate with a broad scope of innovation in their regular day to day existences and become able clients of gadgets, for example, PCs, cell phones, tablets, computer game consoles, computerized video and correspondence based gadgets, with no proper guidance (Clements and Sarama 2003; McKenney and Voogt 2012). During the most recent decade, there has been an overall increment in the utilization of data, and correspondence advances by little youngsters for the most part in the home condition while inquiring about on ICT use in early youth settings has uncovered the beneficial outcomes on small kids' learning and improvement (Ihmeideh and Al-Maadadi 2018).

Advanced innovation helps with building up kids' education abilities as they can learn the jargon and start to recognize the letters of the letter set on the console or in an automated program (Maureen et al., 2018). Instructing an unknown dialect in preschool involves incredible enthusiasm for most nations; they gave specific consideration to early unknown dialect learning to advance plurilingualism across the world (Andúgar and Cortina-Pérez 2018). English has become an inexorably noticeable worldwide language and, inside the Vietnam setting, this is the prevailing/primary unknown dialect all through all degrees of training (the Vietnam setting is quickly introduced in the following segment).

Information communication technology is an auspicious instrument which can encourage instructor's improvement of kids' aptitudes in English as an unknown dialect (EFL) this device that can help youngsters practice different education/language abilities, for example, letter and sound correspondence, talking and tuning in, jargon, and groundwork for perusing and composing (Vungthong 2018; Arias Soto and González Gutiérrez 2019). Youth encounters of education learning in the EFL study hall are a factor that adds to youthful students' inspiration in learning English (Nikolopoulou 2018). Be that as it may, there is constrained observational proof on early childhood student, teacher's view of this issue. According to (Thuy \& Qalati, 2020), study lack of collaboration, technical knowledge, and qualified teachers are critical issues and challenges in Vietnam.

Along these lines, the point of this examination was to look at early youth student teacher's view of small kids' perusing abilities in English as an unknown dialect (EFL) utilizing ICT use in Vietnam. Such an examination is significant on the grounds that students, teacher's observations aim impact their study hall/instructional practices (e.g., their conduct/endeavors to incorporate ICT in preschool classes/settings) and these, thus, influence small kids' learning. We have utilized the term ICT as synonymous with the terms 'PCs' and 'advanced innovation' (counting versatile digital innovation). Verifiably the spotlight has would, in general, be on PCs; however this has stretched out to incorporate intuitive whiteboards and tablets (Jack and Higgins 2018). Aside from PC programming, various items that consolidate a few parts of ICT are accessible to small kids, (for example, electronic melodic consoles, programmable intuitive toys and computerized cameras), while of late versatile advances and, specifically, tablets are famous among little youngsters (Stephen and Edwards 2018). 
British Journal of Education

Vol.8, Issue 3, pp.1-15, March 2020

Published by ECRTD- UK

Print ISSN: ISSN 2054-6351

Online ISSN: ISSN 2054-636X

\section{LITERATURE REVIEW}

\section{Early reading skills in English as a foreign language through ICT}

Students of English as an unknown dialect (EFL) need to procure/practice aptitudes, for example, talking, composing, perusing, tuning in, and jargon (AlNatour and Hijazi 2018; Cerezo et al., 2019). ICT can bolster/help kids' proficiency aptitudes and learning of English as an unknown dialect (Lankshear and Knobel 2003). For instance, youngsters can be presented to sounds, music, and pictures that are joined into a story (making them increasingly anxious to peruse what is on the PC screen), or to local speakers' models to improve right articulation (Al-Awidi and Ismail 2014) by hearing the language or talking it alongside the program. It has additionally been demonstrated that coordinating advanced adding projects to writing programs causes students to improve their understanding of cognizance (Ebrahimi 2016). Frequently, early youth instructive programming overwhelmingly includes pictures, activity and sound, culture-free substance and the lack of bias of graphical interfaces and story-line highlights (Nikolopoulou 2007); in this manner, numerous applications, for example, computerized games, recordings, riddles and melodies in the English language, can pull in consideration of little youngsters around the world. Concentrates demonstrate that $\mathrm{PC}$ programming, long-range informal communication sites, online recordings and sound devices (Alsulami 2016) and cell phone and tablet applications positively affect learning English as an unknown language. Research by Hans (2018) investigated the usage of electronic books (digital books) to build youthful students' proficiency aptitudes in the EFL study hall. For instance, Hamadtoh and Gohar (2017) researched the effect of planning and utilizing an intuitive digital book on the improvement of EFL aptitudes essential for kindergarten youngsters at Egyptian language schools.

Early language abilities (to be specific, word importance, tuning in, print mindfulness, and phonological mindfulness) that should have been aced by kids were focused on the investigation. Their outcomes showed that the trial bunch youngsters outflanked their control partners; regarding tuning in and phonological mindfulness; nonetheless, there were no distinctions in word meaning. They recommended that to augment digital books' advantages, the teacher's essence is significant. Rahimi and Yadollahi (2017) examined the impacts of disconnected versus computerized narrating on the improvement of EFL students' education aptitudes. As per their discoveries, online computerized narrating offers EFL students the chance to build up their language proficiency and invest more energy working with innovation for instructional purposes. Both perusing and composing were upgraded through computerized narrating, mainly when youngsters worked together on the online stage. Numerous different examinations have demonstrated the impact of computerized narrating on inspiration, self-rule, cooperation, and critical thinking abilities (Alcantud-Díaz et al. 2014); oral appreciation (Heidari Soureshjani and Etemadi 2012); speaking (Hwang et al. 2016), and community-oriented composition (Elola and Oskoz 2010).

Cerezo et al. (2019) utilized a holographic versatile based application to help Spanish preschool youngsters in rehearsing the way to express English jargon words. Results showed a critical effect on the youngsters' inspiration and execution. As to computerized versatile innovation, an ongoing 
British Journal of Education

Vol.8, Issue 3, pp.1-15, March 2020

Published by ECRTD- UK

Print ISSN: ISSN 2054-6351

Online ISSN: ISSN 2054-636X

survey (Hwang and Fu 2019) showed that the instructive estimation of portable innovation in language obtaining got acknowledgment and was invited by schools and guardians. Preschool and kindergarten students will be an essential gathering of research subjects if analysts can locate a superior harmony between look into morals and advantages.

Cavus and Ibrahimi (2017) found that a portable application for kids' accounts can be utilized as an instructive device is showing English as a second language since it improves students tuning in, jargon, perception and elocution abilities. Besides, Vatalaro (2015) analyzed the viability of utilizing various sorts of versatile media applications to expand the open and expressive jargon advancement of preschool youngsters. She found that youngsters who utilized direct guidance applications performed necessarily higher on the iPad responsive jargon appraisal (in contrast with kids utilizing open-finished applications or the benchmark groups).

\section{Early childhood teachers and students perceptions}

There is restricted exact proof on early childhood students or teachers' discernments with respect to the utilization of ICT in showing perusing aptitudes in English as an unknown dialect (EFL) to small kids. Al-Awidi and Ismail (2014) discovered positive preschool teacher's observations in regards to youngsters' understanding of abilities and procedures in EFL with ICT. Teachers revealed utilizing PCs to upgrade kids' understanding abilities, tune in to stories read resoundingly, perceive letter/sound connections, and distinguish letters and starting hints of words. Numerous teachers expressed that propelling youngsters to peruse was the principle objective for utilizing PCs, while they utilized the web to display different sites and recordings that acquaint phonics with the kids in a variety of behaviors.

Üstŭn Aksoy and Dimililer (2017) explored the kindergarten teacher's suppositions on portable learning use in youngsters' unknown dialect learning. Concerning explanations behind which versatile learning can be utilized in unknown language instruction teacher's revealed the help of broad media boosts, the straightforward entry to data, the improvement of talking aptitudes, just as the fortification and a good time for youngsters. It was reasoned that learning an unknown dialect through innovation gets, keeps and supports the consideration and inspiration of the two teachers and kids in preschool training. Children's tutoring and language procurement learning were increasingly crucial with the assistance of portable learning intending to the mind-boggling, reasonable critical thinking exercises.

Recio Saucedo (2011) demonstrated that teachers found the utilization of ICT as a positive technique to upgrade little youngsters' learning condition; however they were additionally worried that actualizing ICT-based tasks in the youthful student study hall fundamentally raises issues of school's arrangement for preparing and specialized help, just as contemplations of instructor: kid proportions. Teacher's convictions about the job of ICT for learning are significant in teacher's academic thinking (Webb and Cox 2004) and their convictions regularly limit their endeavors to incorporate ICT into study hall rehearses (Pelgrum 2001). Clearly, except if teachers see new advancements as significant, they will be reluctant or incapable of utilizing them definitively; the 
British Journal of Education

Vol.8, Issue 3, pp.1-15, March 2020

Published by ECRTD- UK

Print ISSN: ISSN 2054-6351

Online ISSN: ISSN 2054-636X

good take-up generally relies upon their perspectives, sentiments and abilities. As an outcome, we underline the significance of exploring early childhood student teacher's observations expectations of youngsters' learning EFL using ICT. As to factors that impact pre-administration and inadministration teacher's perspectives/expectations to utilize innovation in study halls, these incorporate past involvement in innovation, self-adequacy and year of studies or long periods of showing experience (Joo et al., 2018; Myrtil et al., 2018).

\section{Early childhood education in Vietnam}

In Vietnam, ECE minds and teaches youngsters from a half year to 6 years old. Notwithstanding the violent authentic improvements in the other 50\% of the twentieth century, Vietnamese ECE has watched moderately agile development contrasted with other similarly financially distraught nations. At present in Vietnam, there are roughly 12,000 kindergartens with over 3 million youngsters. Training for fewer than 6 is not obligatory in Vietnam; however, the interest is in every case a lot higher than accessible spots. In Vietnam, the English language has been given a unique spot, mainly after the nation chose to grow relations with numerous outside nations during the 1980s. The considerable significance of English in Vietnam is perceived in the public arena and inside each family (Phan, 2004; Nguyen, 2013).

Numerous Vietnamese guardians accept that their kids would be denied chances for business on the off chance that they do not be able to convey easily in English. The Government of Vietnam has unequivocally bolstered and fortified this cultural requirement for English learning in Vietnam. The administration has commanded various significant approaches concerning instructing and learning English at basic, auxiliary and advanced education. At present, college students are required to take English for their graduation tests. Anybody needing to seek after further examinations must get an English declaration.

English turns into a mandatory school subject from grade 3, and all students at each instructive level in 2020 are relied upon to be fit for communicating in English fluidly. Be that as it may, as opposed to the venture into English learning of the legislature and society, the low quality of educating and learning English in various language class settings has been featured in various papers (Phan, 2015; Nguyen, 2016). Likewise, a few endeavors have been made into improving the low English effectiveness levels of language students and teacher's expert information and skills.

Besides, the accompanying exploration addresses all tended to;

- What are the early childhood students and teachers impressions of the utilization of data and correspondence innovation to improve children's skills in EFL learning?

- Is there a noteworthy distinction in student's recognitions concerning specific traits (sex, year of study, and long periods of involvement in ICT)? 


\section{MATERIALS AND METHODS}

The nature of the study was cross-sectional, and data were collected from 100 early childhood teachers and students from Hanoi National University, of Education. Demographical characteristics of students are shown in Table 1, with response rate of gender participation as well as study year with the experience of ICT. Questionnaires were distributed among students in the period of 2018-2019. A total of 120 questionnaires sent to the respondent and the final 100 questionnaires were returned with proper filling. The discard rate of improper and incomplete questionnaires was 20. Teachers and students were picked in light of the fact that they went to the two courses in a similar semester and they were additionally associated with interdisciplinary ventures, for example, planning e-learning exercises in the English language. Students were approached to finish the poll in the English language; their direction of English is fantastic since they have all gone to the previously mentioned module.

Table 1. Demographics Information

\begin{tabular}{llll}
\hline & & Frequency & Percent \\
\hline Gender & Male & 48 & 48.0 \\
& Female & 52 & 52.0 \\
Ttudy Years & Total & $\mathbf{1 0 0}$ & $\mathbf{1 0 0 . 0}$ \\
& 1st Year & 6 & 6.0 \\
& 2nd Year & 16 & 16.0 \\
& 3rd Year & 22 & 22.0 \\
& 4th Year & 26 & 26.0 \\
& More than 4th Year & 30 & 30.0 \\
& Total & $\mathbf{1 0 0}$ & $\mathbf{1 0 0 . 0}$ \\
\hline
\end{tabular}

\section{Measures}

The study adapted questionnaires from the previous study of Al-Awidi and Ismail (2014). Furthermore, the questionnaire was divided into two forms. The first form refers to the student's characteristics. A sample item of students characteristics is "I will use computers for teaching children to segment words into sounds" and second form associated with teacher's perception towards early childhood education. A sample item of teacher perception is "I will use computers to teach the pronunciation of new words." Additionally, to identify early childhood education, further questionnaires involved three factors. The first factor contains 14 items that refer to EFL pre-reading strategies; second, factor contains 11 items which indicates the barriers; third, factor contains 07 items and refers to pre-reading strategies. All the responses were measured using fivepoint Likert-scale referring from 1 strongly disagree to 5 strongly agree. 
British Journal of Education

Vol.8, Issue 3, pp.1-15, March 2020

Published by ECRTD- UK

Print ISSN: ISSN 2054-6351

Online ISSN: ISSN 2054-636X

\section{Data Analysis Technique}

Data were analyzed using software SPSS statistical packages for social sciences. Furthermore, frequency distribution test, descriptive statistics test, factor analysis, correlation analysis and Monto Carlo PCA parallel analysis was performed of collected data to investigate the early childhood education reading skills and teachers perception in Vietnam.

\section{RESULTS AND ANALYSIS}

Frequency Percentage Analysis

Table 2. Student Response to EFL Reading Skills (n=100)

\begin{tabular}{llllll}
\hline EFF Reading Skills & SD & D & N & A & SA \\
\hline EFLRS 1 & & & & & \\
EFLRS 2 & 1.0 & 6.0 & 15.0 & 42.0 & 36.0 \\
EFLRS 3 & 1.0 & 7.0 & 8.0 & 26.0 & 58.0 \\
EFLRS 4 & 0.0 & 2.0 & 19.0 & 51.0 & 28.0 \\
EFLRS 5 & 0.0 & 6.0 & 30.0 & 37.0 & 27.0 \\
EFLRS 6 & 1.0 & 6.0 & 15.0 & 42.0 & 36.0 \\
EFLRS 7 & 0.0 & 0.00 & 11.0 & 45.0 & 44.0 \\
EFLRS 8 & 0.0 & 5.0 & 9.0 & 46.0 & 40.0 \\
EFLRS 9 & 0.0 & 0.0 & 10.0 & 49.0 & 41.0 \\
EFLRS 10 & 0.0 & 3.0 & 11.0 & 51.0 & 35.0 \\
EFLRS 11 & 3.0 & 5.0 & 18.0 & 46.0 & 28.0 \\
EFLRS 12 & 2.0 & 6.0 & 16.0 & 43.0 & 33.0 \\
EFLRS 13 & 0.0 & 0.0 & 4.0 & 46.0 & 50.0 \\
EFLRS 14 & 0.0 & 4.0 & 21.0 & 29.0 & 46.0 \\
\hline Note: EFLRS Englin & 0.0 & 0.0 & 10.0 & 49.0 & 41.0 \\
\hline
\end{tabular}

Note: $\mathrm{EFLRS}=$ English as first language reading skills; $\mathrm{SD}=$ Strongly Disagree; $\mathrm{D}=\mathrm{Disagree}$; $\mathrm{N}=$ Neutral; A=Agree; SA=Strongly Agree; $\mathrm{n}=100$

Table 2 shown that student response on English as first language reading skills EFLRS 02 had high response towards uses of computers for the learning of word formation as well as part of speech and EFLRS 12 response high of students on uses computers to learn the meaning of new words. 
British Journal of Education

Vol.8, Issue 3, pp.1-15, March 2020

Published by ECRTD- UK

Print ISSN: ISSN 2054-6351

Online ISSN: ISSN 2054-636X

Table 3. Student Response on Barriers and EFL Strategies

\begin{tabular}{llllll}
\hline Barriers and EFL Strategies & SD & D & N & A & SA \\
\hline BEFLS1 & & & & & \\
BEFLS2 & 2.0 & 9.0 & 34.0 & 34.0 & 21.0 \\
BEFLS3 & 2.0 & 2.0 & 8.0 & 43.0 & 45.0 \\
BEFLS4 & 0.0 & 0.0 & 23.0 & 43.0 & 34.0 \\
BEFLS5 & 0.0 & 0.0 & 8.0 & 44.0 & 48.0 \\
BEFLS6 & 0.0 & 1.0 & 13.0 & 40.0 & 46.0 \\
BEFLS7 & 0.0 & 3.0 & 20.0 & 43.0 & 34.0 \\
BEFLS8 & 0.0 & 0.0 & 14.0 & 54.0 & 32.0 \\
BEFLS9 & 0.0 & 0.0 & 8.0 & 44.0 & 48.0 \\
BEFLS10 & 0.0 & 3.0 & 7.0 & 47.0 & 43.0 \\
BEFLS11 & 2.0 & 7.0 & 19.0 & 44.0 & 28.0 \\
\hline
\end{tabular}

Note: $\mathrm{BEFLS}=$ English as first language reading strategies; $\mathrm{SD}=$ Strongly Disagree; $\mathrm{D}=\mathrm{Disagree}$; $\mathrm{N}=$ Neutral; A=Agree; $\mathrm{SA}=$ Strongly Agree

Table 3 shown that responses of students on barriers and English as first language strategies; BEFLS 04, 08.11 items had the highest response of students on barriers regarding the uses of computers is restricted by the availability of the researchers as well as computer-based games for children reading.

Table 4. Student Response to EFL Reading Strategies

\begin{tabular}{llllll}
\hline EFL Pre-reading Strategies & SD & D & N & A & SA \\
\hline EFLPRS1 & & & & & \\
EFLPRS2 & 0.0 & 6.0 & 20.0 & 48.0 & 26.0 \\
EFLPRS3 & 0.0 & 3.0 & 19.0 & 32.0 & 46.0 \\
EFLPRS4 & 1.0 & 4.0 & 13.0 & 25.0 & 57.0 \\
EFLPRS5 & 0.0 & 2.0 & 26.0 & 45.0 & 27.0 \\
EFLPRS6 & 0.0 & 4.0 & 7.0 & 35.0 & 54.0 \\
EFLPRS7 & 4.0 & 13.0 & 37.0 & 41.0 & 5.0 \\
\hline
\end{tabular}

Note: $E F L P R S=$ English as first language pre-reading strategies; $S D=$ Strongly Disagree; $\mathrm{D}=$ Disagree; $\mathrm{N}=$ Neutral; $\mathrm{A}=$ Agree; $\mathrm{SA}=$ Strongly Agree

Table 4 shows that the majority of the students expressed strong perceptions-intentions indicating their willingness to use computers to enhance children's reading skills in EFL; more precisely, over $70 \%$ of the sample "agree and strongly agree" with the items. 
British Journal of Education

Vol.8, Issue 3, pp.1-15, March 2020

Published by ECRTD- UK

Print ISSN: ISSN 2054-6351

Online ISSN: ISSN 2054-636X

Explanatory Factor Analysis Test and Correlation Analysis

Table 5. Component Factor, Mean and Standard Deviation Analysis

\begin{tabular}{|c|c|c|c|}
\hline Constructs & $\begin{array}{l}\text { Factor } \\
\text { Loading }\end{array}$ & Mean & S.D \\
\hline \multicolumn{4}{|c|}{ EFF Reading Skills } \\
\hline EFLRS1 & .556 & 4.06 & .919 \\
\hline EFLRS 2 & .669 & 4.33 & .965 \\
\hline EFLRS 3 & .552 & 4.05 & .444 \\
\hline EFLRS 4 & -.487 & 3.85 & .892 \\
\hline EFLRS 5 & .517 & 4.33 & .667 \\
\hline EFLRS 6 & .691 & 3.89 & .827 \\
\hline EFLRS 7 & .452 & 4.21 & .808 \\
\hline EFLRS 8 & .545 & 4.31 & .647 \\
\hline EFLRS 9 & -.587 & 3.91 & .933 \\
\hline EFLRS 10 & .650 & 4.18 & .744 \\
\hline EFLRS 11 & .530 & 3.91 & .965 \\
\hline EFLRS 12 & .450 & 3.99 & .959 \\
\hline EFLRS 13 & .860 & 4.46 & .576 \\
\hline EFLRS 14 & -.690 & 4.17 & .900 \\
\hline \multicolumn{4}{|c|}{ Barriers and EFL Strategies } \\
\hline BEFLS1 & -.557 & 3.63 & .981 \\
\hline BEFLS2 & -.633 & 4.27 & .851 \\
\hline BEFLS3 & -.772 & 4.11 & .751 \\
\hline BEFLS4 & .698 & 4.40 & .636 \\
\hline BEFLS5 & .559 & 4.31 & .734 \\
\hline BEFLS6 & .732 & 4.08 & .813 \\
\hline BEFLS7 & .603 & 4.18 & .657 \\
\hline BEFLS8 & .690 & 4.40 & .636 \\
\hline BEFLS9 & .649 & 4.30 & .732 \\
\hline BEFLS10 & .744 & 3.89 & .963 \\
\hline BEFLS11 & .574 & 4.18 & .999 \\
\hline \multicolumn{4}{|c|}{ EFL Pre-reading Strategies } \\
\hline EFLPRS1 & .615 & 3.94 & .839 \\
\hline EFLPRS2 & -.658 & 4.21 & .856 \\
\hline EFLPRS3 & .612 & 4.33 & .922 \\
\hline EFLPRS4 & .389 & 3.97 & .784 \\
\hline EFLPRS5 & .784 & 4.39 & .790 \\
\hline EFLPRS6 & -.698 & 3.30 & .905 \\
\hline EFLPRS7 & -.345 & 4.29 & .729 \\
\hline
\end{tabular}

Table 5 shows the results of exploratory factors analysis through the principal axis factoring method and the Oblimin rotation method. A total of 33 items were added to the factor analysis to identify the responses of student attitudes. All the results of factor leadings are acceptable to expect item EFLPRS7 had low loading $(<-0.345)$. 
British Journal of Education

Vol.8, Issue 3, pp.1-15, March 2020

Published by ECRTD- UK

Print ISSN: ISSN 2054-6351

Online ISSN: ISSN 2054-636X

Table 6. Correlation Analysis

\begin{tabular}{|c|c|c|c|c|}
\hline & & $\begin{array}{l}\text { EFF Reading } \\
\text { Skills }\end{array}$ & $\begin{array}{l}\text { Barriers and } \\
\text { EFL } \\
\text { Strategies }\end{array}$ & $\begin{array}{ll}\text { EFL } & \text { Pre- } \\
\text { reading } & \\
\text { Strategies } & \end{array}$ \\
\hline EFF Reading Skills & Pearson Correlation & 1 & & \\
\hline $\begin{array}{l}\text { Barriers and EFL } \\
\text { Strategies }\end{array}$ & Pearson Correlation & $.287 * *$ & 1 & \\
\hline $\begin{array}{l}\text { EFL Pre-reading } \\
\text { Strategies }\end{array}$ & Pearson Correlation & $.422 * *$ & $.372^{* *}$ & 1 \\
\hline
\end{tabular}

**Correlation is significant at the 0.01 level

Table 6 results show that all the indicators are positively and significantly correlated with each other. The first factor EFL reading skills and benefits positively correlated with EFL strategies ( $\mathrm{r}$ $=.287, \mathrm{p}<0.05)$ and "EFL pre-reading strategies" $(\mathrm{r}=.422, \mathrm{p}<0.05)$, while "barriers (and EFL strategies)" was also significantly correlated with "EFL pre-reading strategies" $(r=.372, p<0.05)$.

Impact of Students Characteristics (Year of Studies, Years of Experience with ICT) on the Perceptions Factors

Table 7. Perception Factor Scores

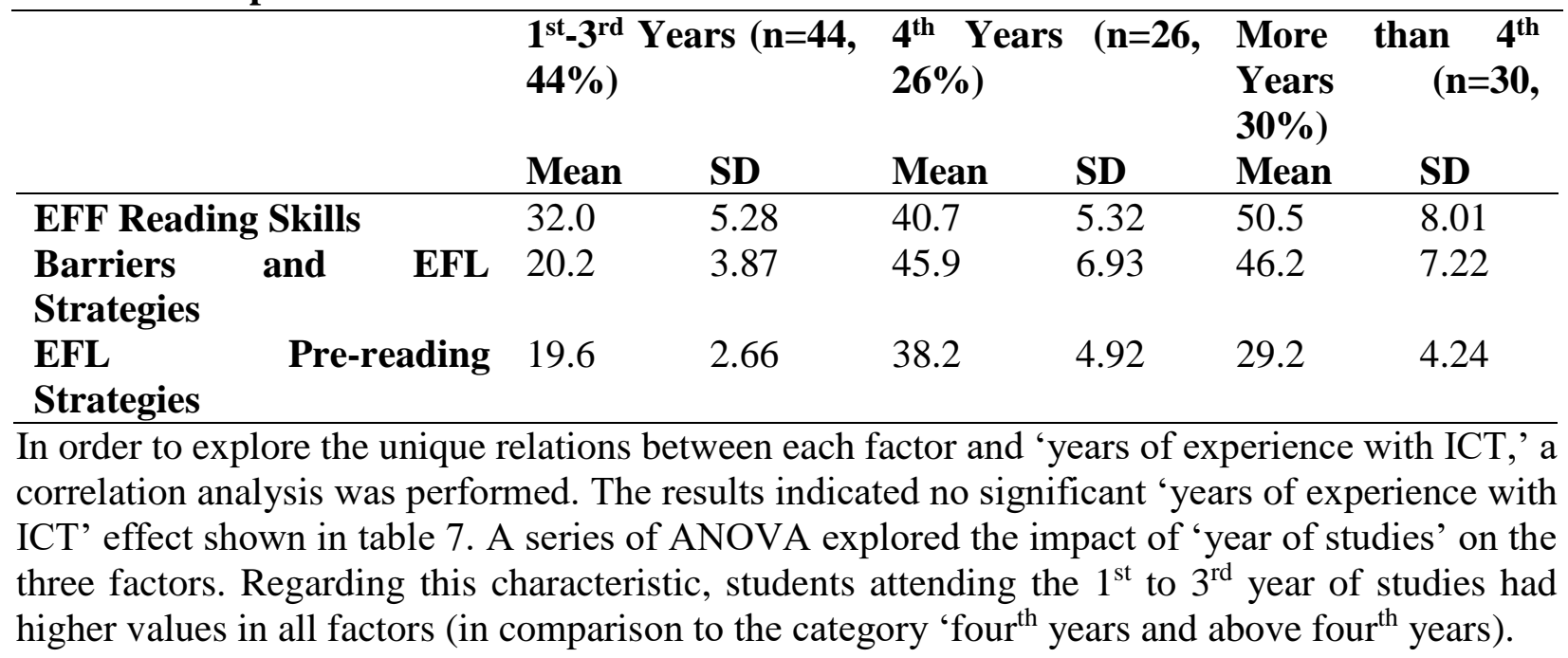

\section{DISCUSSION AND CONCLUSION}

This examination researched early childhood students, teachers' view of small kids' initial perusing skills in EFL employing ICT. Considering that the utilization of ICT in early youth settings is not across the board in Vietnam and that teacher's recognitions expectations impact their conduct in the study hall, we thought about this examination as necessary. The investigation adds to the assemblage of observational proof on student teacher's recognitions aims of utilizing ICT for the 
British Journal of Education

Vol.8, Issue 3, pp.1-15, March 2020

Published by ECRTD- UK

Print ISSN: ISSN 2054-6351

Online ISSN: ISSN 2054-636X

improvement of little youngsters' pre-perusing aptitudes in EFL. Although there is an assortment of proof on kids' improvement of EFL pre-perusing aptitudes through innovation, there is restricted proof on student teacher's discernments/aims at this point.

Concerning the primary research objective, early childhood student teacher's view of the utilization of ICT to improve kids' abilities in EFL learning was specific. Most of the students communicated solid recognitions expectations demonstrating their ability to utilize PCs to improve kids' initial understanding of aptitudes and systems in EFL. At first, there was concurrence with Al-Awidi and Ismail (2014) (whose survey we adjusted) with regards to the elements distinguished and, specifically, concerning the expansion/improvement of youngsters' jargon, the inspiration of kids to peruse and the recognizable proof of starting hints of words. There was likewise a concurrence with different investigations in various nations/societies. Demonstratively, right now, thing "I will utilize PCs to give youngsters extra chances to broaden their jargon" understanding is as per examines demonstrating that teachers trust ICT for jargon improvement (AlNatour and Hijazi 2018; Rahimi and Yadollahi 2017; Cavus and Ibrahimi 2017), and the thing "I will utilize PCs to rouse kids to peruse" concurrence with contemplates showing that ICT use can upgrade understanding execution and spur kids to peruse all the more regularly (Alcantud-Díaz et al. 2014; Cerezo et al. 2019).

Bringing up youngsters' inspiration improves their self-governance when utilizing ICT applications; for instance, in EFL settings, kids' inspiration will prompt recurrent the program commonly, at their own pace, and thus to practice EFL essential aptitudes. Moreover, the thing "I will utilize PCs for instructing youngsters to distinguish starting hints of words" understanding is following investigate showing that ICT use creates EFL listening aptitudes to youthful students (Hamadtoh and Gohar 2017). The positive connections among all components uncover that student's perspectives aim to youngsters' EFL understanding abilities and systems were connected to their perspectives on advantages and hindrances; they all appear to be interrelated in their brains. Students appear to know about the advantages of utilizing ICT in EFL study, e.g., in moving children to improve/stretch out their jargon or to peruse (concurrence with Üstŭn Aksoy and Dimililer 2017, who explored teacher's perspectives). Also, students communicated reliable observations with regards to the obstructions blocking the utilization of PCs in showing small children EFL. The obstructions of specialized help and assets were likewise revealed before the investigation in early youth settings (Recio Saucedo 2011; Al-Awidi and Ismail 2014; Nikolopoulou and Gialamas 2015).

\section{Limitations, Practical Implication and Future Directions}

Limitations of this examination incorporate the size of the example and the utilization of a quantitative request as it were. Student's appreciations can be additionally investigated with more prominent examples and by likewise utilizing open-finished inquiries. Also, the effect of students ICT self-adequacy on their observations/expectations could be examined. The discoveries of this examination have suggestions for student teacher's pre-administration preparation: students need to recognize the capability of innovation in EFL educating and learning and have the option to 
British Journal of Education

Vol.8, Issue 3, pp.1-15, March 2020

Published by ECRTD- UK

Print ISSN: ISSN 2054-6351

Online ISSN: ISSN 2054-636X

furnish youngsters with fitting encounters to improve their EFL aptitudes. Related modules need to consider student teachers observations aims and manage them as needs be (e.g., essential judgment, improvement of positive perspectives).

Inside the "ICT joining in early youth instruction" module, students assess instructive programming and sites expected for little youngsters. Student's preparation is proposed to expand their attention to fitting projects/applications that target early perusing aptitudes in EFL and request that they structure instructive situations and learning exercises coordinating the utilization of such projects. Likewise, inside the "English Educational phrasing" module, student teachers gain the essential information, comprehension, and aptitudes for showing English language and proficiency in their future vocations. It is firmly recommended that students, teachers, are included in essential, instructive practices with kindergarten youngsters, incorporating innovation in EFL learning.

Teacher preparing programs were seen as helpful in decreasing the hindrances which were thwarting the coordination of ICT into kindergarten showing rehearses (Ihmeideh and Al-Maadadi 2018), just as in changing kindergarten teacher's language convictions concerning EFL (Pocinho et al. 2018). It is recommended that early youth instructive approach consider the conceivable outcomes of ICT in supporting youngsters' learning in EFL, and think about financing in order to beat explicit hindrances (e.g., specialized help, assets) that forestall innovation use in early youth settings.

Examining teacher's discernments/aims is the initial step since these are relied upon to impact their homeroom rehearses and, like this, kids are learning. Youth encounters of learning in the EFL study hall add to youthful students' inspiration in learning English (Hans 2018), while ICT can bolster the instructing learning of EFL in early youth training. The survey could be adjusted and utilized with other objective populaces to recognize potential similitudes and contrasts. We intend to do a similar kind of concentrate with rehearsing teachers by including the poll open-finished inquiries that would test correct settings, limitations and related potential outcomes. An online line-up study with this gathering of students (after they graduate) is arranged to enhance the present information. Of late, new portable applications (with new highlights/characteristics) which run in tablets target little youngsters (Papadakis et al. 2018). Future research is recommended to explore (I) early youth teacher's recognitions and practices on this subject and (ii) little youngsters' preperusing abilities in EFL, practiced by means of various ICT applications/apparatuses.

\section{References}

Al-Awidi, H. M., \& Ismail, S. A. (2014). Teachers' perceptions of the use of computer assisted language learning to develop children's reading skills in English as a second language in the United Arab Emirates. Early Childhood Education Journal, 42(1), 29-37.

Alcantud-Díaz, M., Ricart-Vayá, A., \& Gregori-Signes, C. (2014). Share your experience. Digital storytelling in English for tourism. Ibérica, 27, 185-204. 
British Journal of Education

Vol.8, Issue 3, pp.1-15, March 2020

Published by ECRTD- UK

Print ISSN: ISSN 2054-6351

Online ISSN: ISSN 2054-636X

AlNatour, A. S., \& Hijazi, D. (2018). The impact of using electronic games on teaching English vocabulary for kindergarten students. US-China Foreign Language, 16(4), 193-205.

Alsulami, S. (2016). The effects of technology on learning English as a Foreign Language among female EFL students at Effatt College: An exploratory study. Studies in Literature and Language, 12(4), 1-16.

Andúgar, A., \& Cortina-Pérez, B. (2018). EFL teachers' reflections on their teaching practice in Spanish preschools: A focus on motivation. In M. Schwartz (Ed.), Preschool Bilingual Education. Multilingual Education (Vol. 25, pp. 219-244). Cham: Springer.

Arias Soto, L., \& González Gutiérrez, Y. (2019). Digital literacy and basic self-regulation habits in early childhood learning of English as a Foreign Language. Folios, 49, 177-196.

Cavus, N., \& Ibrahimi, D. (2017). Learning English using children's stories in mobile devices. British Journal of Educational Technology, 48(2), 625-641.

Cerezo, R., Calderón, V., \& Romero, C. (2019). A holographic mobile-based application for practicing pronunciation of basic English vocabulary for Spanish speaking children. International Journal of Human-Computer Studies, 124, 13-25.

Clements, D., \& Sarama, J. (2003). Strip mining for gold: Research and policy in educational technology - A response to 'Fool's Gold'. Educational Technology Review, 11(1), 7-69.

Ebrahimi, S. S. (2016). Effect of digital reading on comprehension of English prose texts in EFL/ESL contexts. International Journal of English Language and Literature Studies, 5(2), 111-117.

Elola, I., \& Oskoz, A. (2010). Collaborative writing: Fostering foreign language and writing conventions development. Language Learning \& Technology, 14, 51-71.

Hamadtoh, R., \& Gohar, A. G. (2017). The impact of a proposed $\backslash$ interactive e-book on developing English language skills of kindergarten children. International Journal of Internet Education. Retrieved from http://ijie.journ als.ekb.eg/.

Hans, D. M. (2018). The concept of animated electronic books in increasing young learners' literacy skills in EFL classroom. Pedagogy: Journal of English Language Teaching, 6(1), 57-64.

Heidari Soureshjani, K., \& Etemadi, N. (2012). Listening comprehension success among EFL preschool children using internet based materials. Journal of Social Sciences and Humanities, 7, 243-251.

Hwang, G.-J., \& Fu, Q.-K. (2019). Trends in the research design and application of mobile language learning: A review of 2007-2016 publications in selected SSCI journals. Interactive Learning Environments, 27(4), 567-581.

Hwang, W. Y., Shadiev, R., Hsu, J. L., Huang, Y. M., Hsu, G. L., \& Lin, Y. C. (2016). Effects of storytelling to facilitate EFL speaking using web-based multimedia system. Computer Assisted Language Learning, 29, 215-241.

Ihmeideh, F. (2010). The role of computer technology in teaching reading and writing: Preschool teachers' beliefs and practices. Journal of Research in Childhood Education, 24(1), 60-79.

Ihmeideh, F., \& Al-Maadadi, F. (2018). Towards improving kindergarten teachers' practices regarding the integration of ICT into early years settings. The Asia-Pacific Education Researcher, 27(1), 65-78. 
British Journal of Education

Vol.8, Issue 3, pp.1-15, March 2020

Published by ECRTD- UK

Print ISSN: ISSN 2054-6351

Online ISSN: ISSN 2054-636X

Jack, C., \& Higgins, S. (2018). What is educational technology and how is it being used to support teaching and learning in the early years? International Journal of Early Years Education. https ://doi. org/10.1080/09669 760.2018.1504754.

Joo, Y. J., Park, S., \& Lim, E. (2018). Factors influencing pre-service teachers' intention to use technology: TPACK, teacher self-efficacy, and technology acceptance model. Educational Technology \& Society, 21(3), 48-59.

Lankshear, C., \& Knobel, M. (2003). New technologies in early childhood literacy research: A review of research. Journal of Early Childhood Literacy, 3(1), 59-82.

Maureen, I. Y., van der Meij, H., \& de Jong, T. (2018). Supporting literacy and digital literacy development in early childhood education using storytelling activities. International Journal of Early Childhood, 50(3), 371-389.

McKenney, S., \& Voogt, J. (2012). Teacher design of technology for emergent literacy: An explorative feasibility study. Australasian Journal of Early Childhood, 37(1), 4-12.

Myrtil, M. J., Justice, L. M., Pelfrey, L., Logan, J. A., Xie, K., \& Barnes, L. (2018). Preschool teachers' implementation fidelity when using a technology-mediated language and literacy intervention. Child \& Youth Care Forum, 47(6), 771-786.

Narayan, N. A. (2016). Factors influencing teacher career satisfaction, teacher collaboration and everyday challenges: An exploratory factor analysis, Malaysian Online Journal of Educational Sciences, 4(3), 24-38.

Nikolopoulou, K. (2007). Early childhood educational software: Specific features and issues of localization. Early Childhood Education Journal, 35(2), 173-179.

Nikolopoulou, K. (2018). Mobile technologies and early childhood education. In M. Tsitouridou, J.A. Diniz, T.A. Mikropoulos, \& S. Hadjileontiadou (Eds.), Proceedings of the 1st International Conference on Technology and Innovation in Learning, Teaching and Education-TECH-EDU 2018, Aristotle University of Thessaloniki, Greece. Berlin: Springer.

Nikolopoulou, K., \& Gialamas, V. (2009). Investigating pre-service early childhood teachers' views and intentions about integrating and using computers in early childhood settings: compilation of an instrument. Technology, Pedagogy and Education, 18(2), 201-219.

Nikolopoulou, K., \& Gialamas, V. (2015). Barriers to the integration of computers in early childhood settings: Teachers' perceptions. Education and Information Technologies, 20(2), 285-301.

Papadakis, S., Kalogiannakis, M., \& Zaranis, N. (2018). Educational apps from the Android google play for Greek preschoolers: A systematic review. Computers \& Education, 116, 139-160.

Pelgrum, W. (2001). Obstacles to the integration of ICT in education: Results from a worldwide educational assessment. Computers \& Education, 37(2), 163-178.

Phan, H. L. (2004). University classrooms in Vietnam: Contesting the stereotypes. ELT Journal, 58(1), 50-57.

Phan, N. T. T. (2015). Can I teach these students? A case study of Vietnamese teachers' selfefficacy in relation to teaching English as a foreign language (Doctoral thesis). University of Waikato. Retrieved from http://hdl.handle.net/10289/9433 
British Journal of Education

Vol.8, Issue 3, pp.1-15, March 2020

Published by ECRTD- UK

Print ISSN: ISSN 2054-6351

Online ISSN: ISSN 2054-636X

PI. (2011). Nursery school program, Part 1, Pedagogical framework and principles of the nursery school program. Retrieved from http://archi ve.is/20121 21809 4948/digit alsch ool5.mined u.gov.gr/ info/newps .php.

Pocinho, M., Olczak, A., \& Franicka, M. (2018). Bilingual language acquisition in preschool age: The emotional context of kindergarten daily routines. Issues in Early Education, 1(40), 3039.

Rahimi, M., \& Yadollahi, S. (2017). Effects of offline vs. online digital storytelling on the development of EFL learners' literacy skills. Cogent Education, 4(1), 1285531.

Recio Saucedo, A. (2011) Exploring the impact of using stories and ICT to teach English to three and four-year-old Spanish children: Motivation and development. At Edulearn International Conference on Education and New Learning Technologies. Spain, 04-06 July 2011.

Stephen, C., \& Edwards, S. (2018). Young children playing and learning in a digital age: A cultural and critical perspective. London: Routledge.

Thuy, T. T. H., \& Qalati, S. A. (2020). Preschool Teacher's Attitude towards the Integration of Information Technology into English Teaching for Young Children in Vietnam. International Journal of Economics, Commerce and Management, VIII(2), 279-294.

Üstŭn Aksoy, Y., \& Dimililer, C. (2017). Teacher opinions on usage of mobile learning in preschool foreign language learning. EURASIA Journal of Mathematics Science and Technology Education, 13(8), 5405-5412.

Vatalaro, A. (2015). A quasi-experiment examining expressive and receptive vocabulary knowledge of preschool head start children using mobile media apps. Electronic Theses and Dissertations, p. 728. Retrieved from http://stars .libra ry.ucf.edu/etd/728.

Vungthong, S. (2018). The roles of visual design in tablet games for children's EFL learning: A social semiotic perspective. Reflections, 25(1), 46-60.

Watkins, M. W. (2000). Monte Carlo PCA for parallel analysis (computer software). State College, PA: Ed \& Psych Associates.

Webb, M., \& Cox, M. (2004). A review of pedagogy related to information and communications technology. Technology, Pedagogy and Education, 13(3), 235-286. 